\title{
ESTIMATING LONG-TERM CARBON ACCUMULATION RATES IN BOREAL PEATLANDS BY RADIOCARBON DATING
}

\author{
ATTE KORHOLA, ${ }^{1}$ KIMMO TOLONEN, ${ }^{2}$ JUKKA TURUNEN ${ }^{2}$ and HÖGNE JUNGNER ${ }^{3}$
}

\begin{abstract}
We used direct radiocarbon dates of peat samples, pollen dates and land-uplift chronology from $>1300$ cores comprising all or most of the Holocene in the boreal region of Finland, Estonia and Maine (USA) to obtain long-term carbon accumulation rates for boreal peatlands. The "apparent" long-term rate of carbon accumulation (LORCA; $\mathrm{g} \mathrm{C} \mathrm{m}^{-2} \mathrm{a}^{-1}$ ) ranged from 4.6 to 85.8 (mean $19.9 \pm 10.7$ ), depending on the geographical location, wetland type and the age of the mire. The "true" or "actual" rate of carbon accumulation (ARCA), as derived from models for peatbog growth, was usually ca. $70 \%$ of LORCA. We studied the raised bog Reksuo more intensely in terms of growth dynamics, and we report preliminary results of the "three-dimensional" or spatial carbon accumulation rates. These results strongly contradict the concept of constant input and constant decay throughout the millennia. The study emphasizes the importance of exploring the formation and dynamics of entire mire ecosystems, and the role of carbon in these systems, in addition to studying single cores.
\end{abstract}

\section{INTRODUCTION}

Mire ecosystems maintain themselves by disproportionate plant production (input) and decay (output); ca. $5-10 \%$ of the yearly produced plant biomass accumulates in the form of peat and, consequently, does not return to the nutrient cycle (Gorham 1991; Warner, Clymo and Tolonen 1993; Gorham and Janssens 1993). This makes natural peatlands net accumulators of organic matter, and thus, an important component of the global carbon cycle, with ca. $192-455 \mathrm{PgC}\left(=10^{15} \mathrm{~g}\right)$ stored in peats of boreal wetlands (Gorham 1991). Most of this peatland carbon is potentially available for exchange with the atmosphere, and a changing climate can be expected to have an impact on all environmental variables contributing to the fluxes (Billings 1987; Crill, Bartlett and Roulet 1992). To be able to predict future change in peatland ecosystems and under changing climatic conditions, one must understand the processes regulating the retention and release of elements in mire environments.

Assessment of modern terrestrial inventories alone will not provide sufficient information to predict future sinks and sources for atmospheric $\mathrm{CO}_{2}$. Determining carbon storage in peat, its long-term variations and climatic controls are required to understand and model the dynamics of carbon in peatland ecosystems (Harden et al. 1992; Tolonen et al. 1992a). Here we present results obtained by direct ${ }^{14} \mathrm{C}$ dating of peat that link long-term carbon accumulation with growth dynamics of peatland ecosystems (see, e.g., Foster and Wright, Jr. 1990; Korhola 1992, 1994).

\section{METhodS}

To calculate the long-term (apparent) rate of carbon accumulation (LORCA) at a site on a mire, one needs reliable dating for the deepest peat, known stratigraphy and measured profile of (dry) bulk density and carbon content. Some 200 locations in boreal Europe and North America meet all four requirements (Gorham 1991; Zoltai 1991; Tolonen et al. 1992a). Here we focus mainly on extensive Finnish samples. A large part of these data is published in the preliminary report by Tolonen et al. (1994).

We sampled most of the peatlands during the summers of 1991-1993, using a $8 \times 8-\mathrm{cm}$ box corer (length 90,100 or $150 \mathrm{~cm}$ ) and a Russian peat sampler $(10 \times 50$ or $5 \times 50 \mathrm{~cm})$. Subsamples of known \footnotetext{
${ }^{1}$ Department of Geography, Laboratory of Physical Geography, P.O. Box 9 (Siltavuorenpenger 20 A), FIN-00014 University
of Helsinki, Finland

${ }^{2}$ Department of Biology, University of Joensuu, P.O. Box 111, FIN-80101 Joensuu, Finland

${ }^{3}$ Dating Laboratory, P.O. Box 11 (Snellmaninkatu 3), FIN-00014 University of Helsinki, Finland
} 
volume were taken at $10-\mathrm{cm}$ intervals; the samples were oven-dried at $105^{\circ} \mathrm{C}$, ashed at $500^{\circ} \mathrm{C}$, and bulk densities were calculated from the dry mass and fresh-volume values.

We ${ }^{14} \mathrm{C}$ dated $>300$ samples comprising all or most of the Holocene. Most of the samples were dated at the Dating Laboratory of the University of Helsinki (Hel), according to standard procedures. The dates were corrected for isotopic fractionation, and converted to calendar years using the CALIB program (version 3.0.3: Stuiver and Reimer 1993); a one-sigma standard deviation estimate was applied. Many of the dates were published (Tolonen et al. 1992a, 1994; Korhola 1992), but some were not reported previously (cf. Table 2 below). The complete list of the study sites with the mire type descriptions and radiocarbon results is available by request from $\mathrm{K}$. Tolonen.

LORCA was determined according to the following equation (dry mass estimate of $\mathrm{C} 0.5$ )

$$
A=r \rho
$$

where $A=$ dry mass accumulation $\left(\mathrm{g} \mathrm{m}^{-2} \mathrm{a}^{-1}\right), \mathrm{r}=$ net rate of height increment $\left(\mathrm{mm} \mathrm{a}^{-1}\right)$ and $\rho=$ bulk density of dry peat $\left(\mathrm{g} \mathrm{cm}^{-3}\right)$.

The actual ("true") net rate of carbon accumulation (ARCA), however, is lower than LORCA because of the slow plant decay in the anoxic thicker peat column (Clymo 1984; Tolonen et al. 1992a). The actual rate can be estimated only by using theoretical peat accumulation models, in which a concave relation is assumed for age vs. depth plots in peat profiles (Clymo 1984). We used the following equation to determine ARCA

$$
A=\mathrm{pe}^{-\alpha \mathrm{t}}
$$

where $\mathrm{A}=$ net rate of dry mass accumulation $\left(\mathrm{g} \mathrm{m}^{-2} \mathrm{a}^{-1}\right), \mathrm{p}=$ rate of dry matter addition $\left(\mathrm{g} \mathrm{m}^{-2} \mathrm{a}^{-1}\right)$, $\alpha=$ decay cofficient as a proportion $\left(\mathrm{a}^{-1}\right)$ and $\mathrm{t}=$ time (a). We calculated numerical values for parameters $\alpha$ and p using a computer program provided by R. S. Clymo, University of London.

Precise dates of peat strata are of crucial importance to studies of peatland carbon budgets. Our profiles were dated by ${ }^{14} \mathrm{C}$ ( 257 cores), by palynology ( 238 cores) or by land-uplift chronology ( 823 cores). We used series of vertical ${ }^{14} \mathrm{C}$ dates (minimum of 7 dates per core) to estimate ARCA and single basal peat ${ }^{14} \mathrm{C}$ dates to calculate the overall (top to bottom) average LORCA. We obtained the palynological dates by comparing the pollen record from basal peat sequences against long ${ }^{14} \mathrm{C}$ dated standard diagrams. When using land-uplift chronology, we assumed no time gap between the emergence of the site and the onset of peat accumulation.

To gain better understanding of the spatial carbon accumulation in the entire peat mass, we carried out more detailed studies in Reksuo, a concentrically domed bog in southern Finland $\left(60^{\circ} 37^{\prime} \mathrm{N}\right.$, $23^{\circ} 16^{\prime} \mathrm{E} ; 577 \mathrm{ha} ; 88.0 \mathrm{~m}$; see Korhola (1992) for a more detailed description of the mire). We studied the bog's topography, peat stratigraphy, mire formation and growth dynamics, and measured ${ }^{14} \mathrm{C}$ dates from vertical profiles and basal peats along a network of transects. We present here only preliminary results concerning the spatial or three-dimensional carbon accumulation in the Reksuo bog.

\section{RESULTS}

Average LORCA showed great variation in our database depending on the geographical location, the wetland type, the age of the deposit and the number of mire fires. In the extensive samples for Finland, we found a mean of $19.9 \pm 10.7 \mathrm{~g} \mathrm{C} \mathrm{m}^{-2} \mathrm{a}^{-1}$, range 4.6-85.8 (Fig. 1), and observed a clear increase in LORCA with decreasing mire age. The most pronounced change, especially in maximum values, occurred ca. $4500 \mathrm{BP}$. Carbon has accumulated more in ombrotrophic bogs ( $22.5 \pm 11.5$ $\mathrm{g} \mathrm{C} \mathrm{m}^{-2} \mathrm{a}^{-1}$, range 6.6 to $\left.85.5, \mathrm{n}=548\right)$ than in minerotrophic fens $\left(15.1 \pm 6.8 \mathrm{~g} \mathrm{C} \mathrm{m}^{-2} \mathrm{a}^{-1}\right.$, range 4.6 
to $49.1, \mathrm{n}=373$ ) (Fig. 2), and accumulation rates have been generally higher in treeless and pine fens than in spruce-alder mires. Where repeated mire fires were common, the average LORCA was only $1 / 2$ or $1 / 3$ from that in the unburned deposits with corresponding age, location and plant cover.

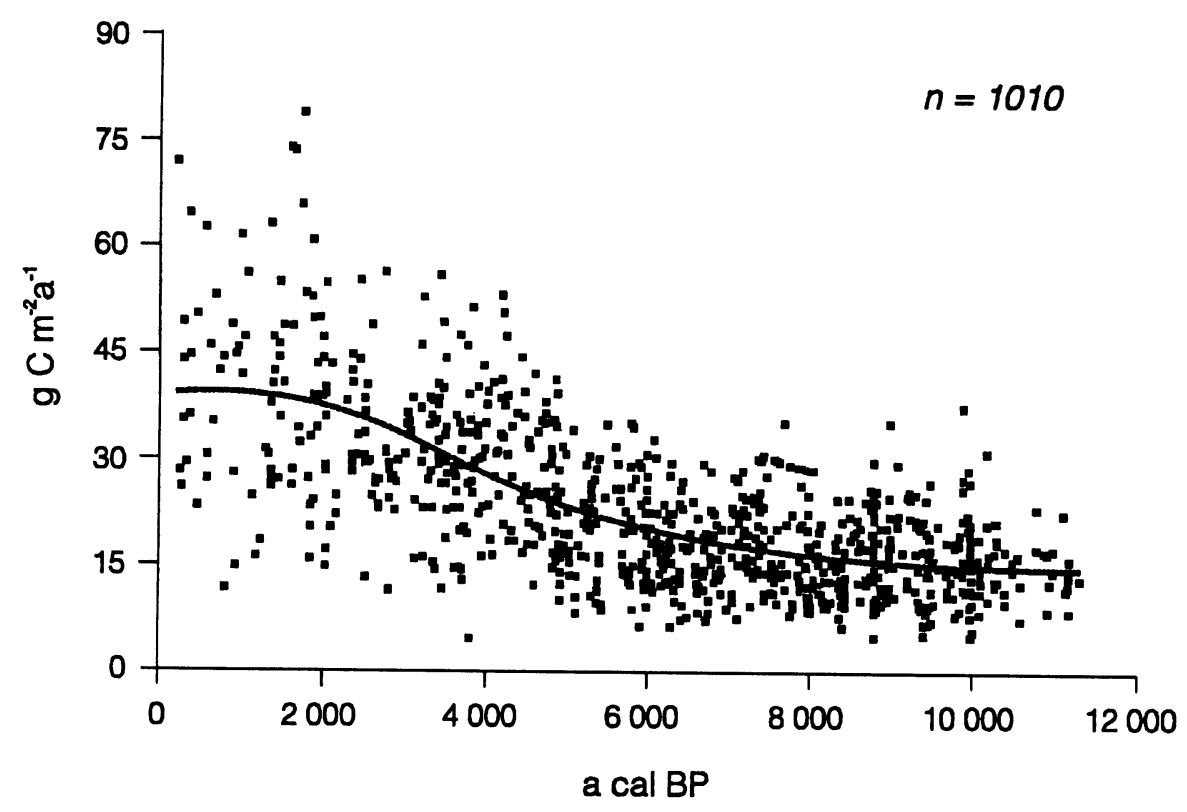

Fig. 1. LORCA( $\left(\mathrm{g} \mathrm{C} \mathrm{m}^{-2} \mathrm{a}^{-1}\right) v s$. age (cal yr BP) of basal peat in dated peat columns with known bulk density. The line is a splined regression formed from three $\mathbf{x}$-axis segments.

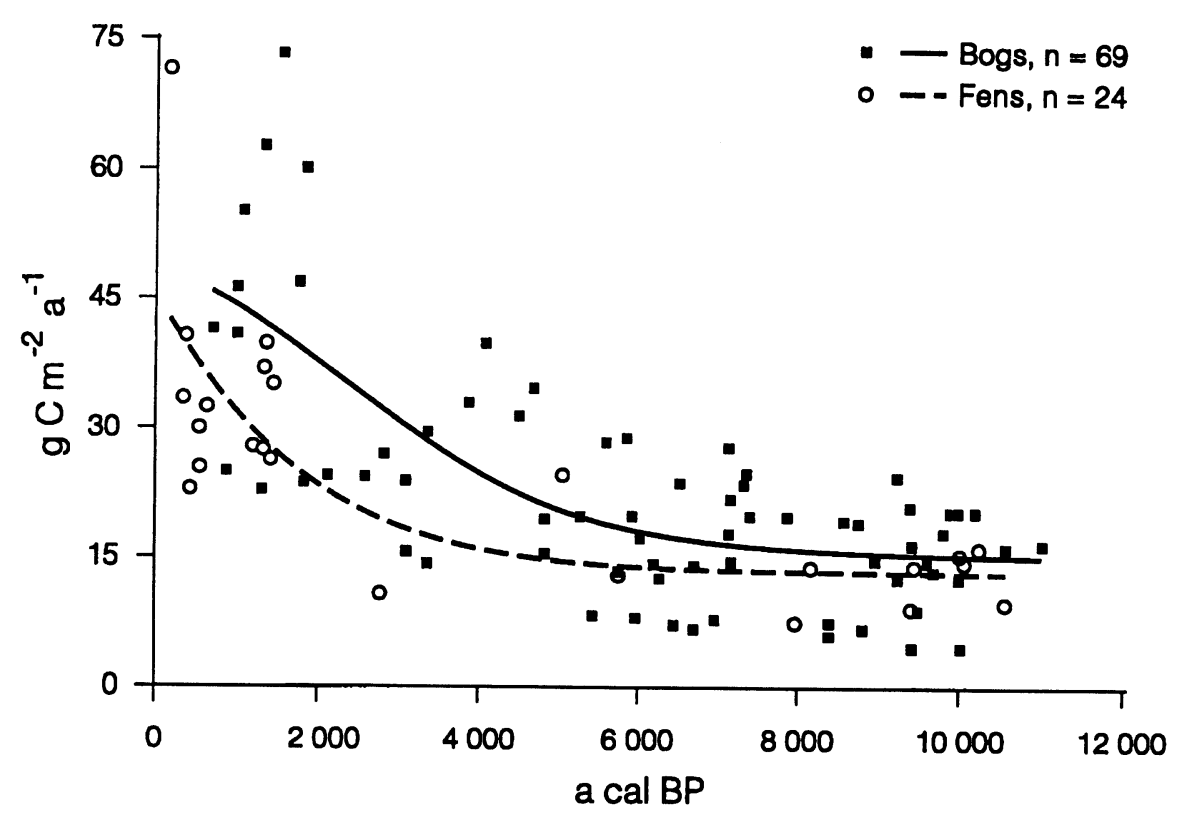

Fig. 2. LORCA $\left(\mathrm{g} \mathrm{C} \mathrm{m}^{-2} \mathrm{a}^{-1}\right)$ vs. age (cal yr BP) of basal peat for two main hydrological types of mires of Finland. The two lines are splined regressions formed from three $x$-axis segments. Number of mires: hemiboreal - 13; southern boreal - 28, middle boreal - 29, northern boreal - 14 (from Tolonen et al. 1994). 
Regardless of the mire type, LORCA was much higher in southern than in northern mires (Fig. 3). The most pronounced feature indicated by the diagram is the abrupt decline in LORCA for northern mires and the reciprocal increase in accumulation rates for southern bogs after ca. $2000 \mathrm{cal} \mathrm{BP}$. This phenomenon may be an artifact of the plotting, but may equally well be real. The latter conclusion is supported by observations already made by Rancken (1912), according to which the current peat accumulation in the northern aapa mires is an extremely slow process. Some unpublished ${ }^{14} \mathrm{C}$ dates from individual peat profiles of mires in northern Finland further confirm slow peat accumulation during the latter part of the Holocene (K. Tolonen and R. Ruuhijärvi, unpublished data; H. Hyvärinen, personal communication).

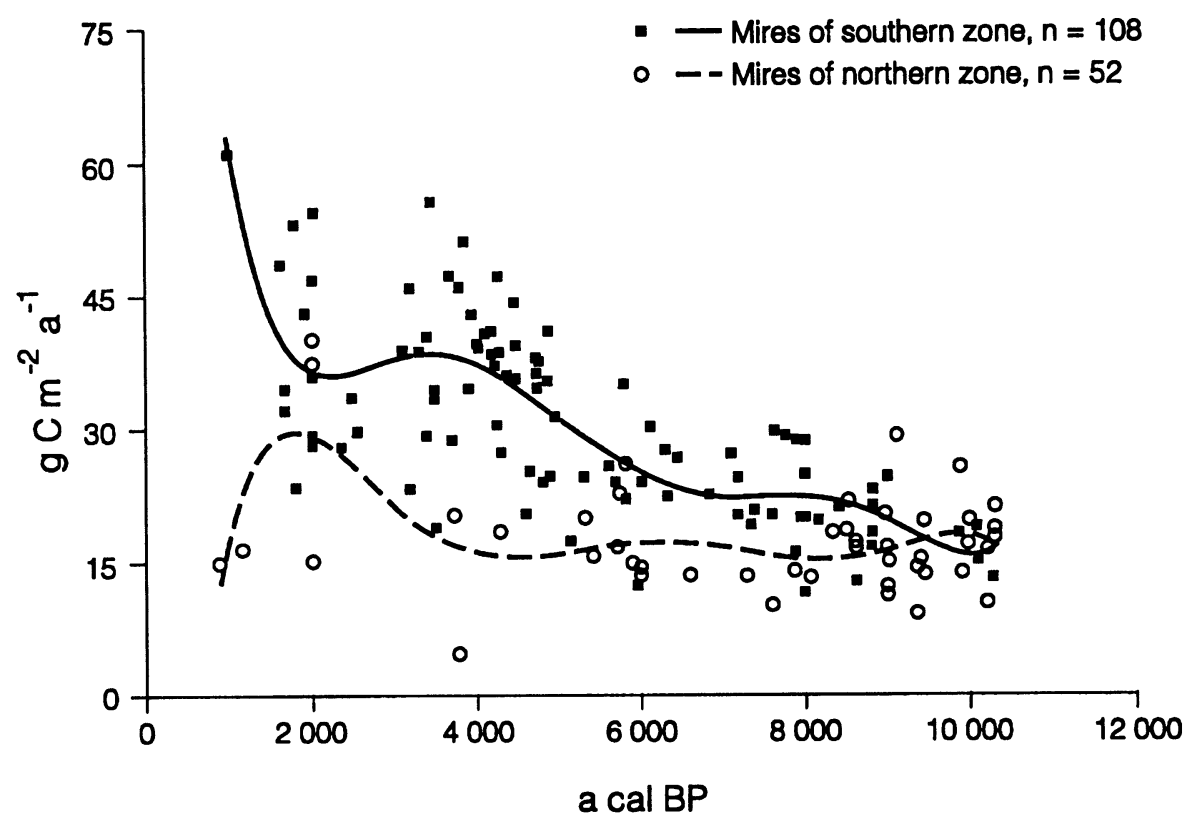

Fig. 3. LORCA $\left(\mathrm{g} \mathrm{C} \mathrm{m}^{-2} \mathrm{a}^{-1}\right) v s$. age (cal yr BP) of basal peat in dated peat columns in southern (approximately equal to hemiboreal) and in northern (equal to northern boreal) zone in Finland. In the southern zone, 98 sites are bogs and $10 \mathrm{fens}$; in the northern zone, 14 are bogs and $34 \mathrm{fens}$. In age group 0-4000 yr, LORCA was 36.3 $\pm 11.6 \mathrm{~g} \mathrm{C} \mathrm{m}^{-2} \mathrm{a}^{-1}$ (mean age $2786 \mathrm{a}$ ) in the southern zone, and $21.2 \pm 11.9 \mathrm{~g} \mathrm{C} \mathrm{m}^{-2} \mathrm{a}^{-1}$ (mean age $2221 \mathrm{a}$ ) in the northern zone. The two lines are splined regressions formed from six $x$-axis segments (revised from Tolonen et al. 1994)

ARCA ranged between 8.1 and $23.0 \mathrm{~g} \mathrm{C} \mathrm{m}^{-2} \mathrm{a}^{-1}$ (mean 12.1) and was 29-85\% (mean 63\%) of the LORCA in the individual peat columns (Table 1). The calculated loss by decay and associated processes varied from 7.1-31.3 $\mathrm{g} \mathrm{C} \mathrm{m}^{-2} \mathrm{a}^{-1}$ (mean 19.2 \pm 7.3 ), whereas the average current sequestering percentage of carbon was $57 \pm 24 \%$. In several peatlands, the vertical growth contradicted the concave plot predicted for age $v s$. depth by Clymo's (1984) model of peat growth, a fact that made impossible the estimate of ARCA using existing models. Consequently, only the cases that are in accordance with the framework provided by the theoretical model are reported in Table 1.

In the case of Reksuo, we have thus far collected $34{ }^{14} \mathrm{C}$ dates: 17 from the basal peat sections and 17 from the vertical peat profiles (Table 2). The average LORCA (top to bottom) varied from 8.7$33.7 \mathrm{~g} \mathrm{C} \mathrm{m}^{-2} \mathrm{a}^{-1}$ (mean 24.6) in the 16 study cores with basal peat dates and calculated bulk densities 
TABLE 1. ARCA and LORCA (cf. Fig. 1) in 5 fens (nos. 1-4) and 10 bogs from Finland, and in 1 bog from Estonia (no.15) and 1 from Maine, USA (no. 16) as calculated by Clymo's (1984) model. Slightly modified
from Tolonen et al. (1994).

\begin{tabular}{|c|c|c|c|c|c|c|c|c|}
\hline & $\begin{array}{l}\text { Location } \\
\text { (N lat) }\end{array}$ & $\begin{array}{c}\begin{array}{c}\text { Site } \\
\text { (type)* }\end{array} \\
\end{array}$ & $\begin{array}{c}\text { Depth } \\
\text { (m) }\end{array}$ & $\begin{array}{c}\text { Age } \\
\text { (cal yr BP) }\end{array}$ & $\begin{array}{c}\text { LORCA } \\
\left(\mathrm{g} \mathrm{m}^{-2} \mathrm{a}^{-1}\right)\end{array}$ & $\begin{array}{c}\text { ARCA } \\
\left(\mathrm{g} \mathrm{m}^{-2} \mathrm{a}^{-1}\right)\end{array}$ & $\begin{array}{c}\text { LOSS } \dagger \\
\left(\mathrm{g} \mathrm{m}^{-2} \mathrm{a}^{-1}\right)\end{array}$ & $\begin{array}{c}\text { SEQU } \ddagger \\
(\%)\end{array}$ \\
\hline 1. Silmäsvuoma & $67^{\circ} 33^{\prime}$ & RiL & 1.7 & 9440 & 9.6 & 10.7 & 4 & 97 \\
\hline 2. Ahvensalo & $62^{\circ} 46^{\prime}$ & RhSK & 2.0 & 9570 & 14.7 & 12.5 & 313 & 29 \\
\hline 3. Siikaneva & $61^{\circ} 46^{\prime}$ & SSN & 7.2 & 9040 & 19.2 & 14.0 & 43 & 76 \\
\hline 4. Suurisuo & $61^{\circ} 00^{\prime}$ & RhSN & 3.7 & 5070 & 24.9 & 17.7 & 143 & 55 \\
\hline 5. Särkänsuo & $62^{\circ} 45^{\prime}$ & RaR & 3.4 & 10,230 & 18.6 & 14.2 & 195 & 84 \\
\hline 6. Korvinsuo & $62^{\circ} 45^{\prime}$ & $\mathrm{KeR}$ & 4.4 & 10,200 & 16.5 & 12.1 & 195 & 76 \\
\hline 7. Korvinsuo & $62^{\circ} 45^{\prime}$ & IR & 2.8 & 10,090 & 13.7 & 10.9 & 1 & 92 \\
\hline 8. Korkianeva & $62^{\circ} 45^{\prime}$ & RaLkN & 3.4 & 5970 & 20.2 & 9.3 & 198 & 32 \\
\hline 9. Kunoniemensuo & $62^{\circ} 05^{\prime}$ & IR & 4.3 & 7170 & 18.1 & 8.1 & 98 & 45 \\
\hline 10. Lakkasuo & $61^{\circ} 45^{\prime}$ & KeR & 2.7 & $\sim 3000$ & 24.7 & 12.3 & 195 & 35 \\
\hline 11. Kaurastensuo & $61^{\circ} 01^{\prime}$ & $\mathrm{KeR}$ & 5.2 & 9810 & 18.3 & 10.9 & 71 & 60 \\
\hline 12. Laaviosuo & $61^{\circ} 01^{\prime}$ & $\mathrm{KeR}$ & 5.4 & 10,190 & 20.8 & 12.8 & 172 & 43 \\
\hline 13. Varrassuo & $61^{\circ} 00^{\prime}$ & KeR & 4.4 & 6670 & 17.2 & 11.1 & 175 & 39 \\
\hline 14. Munasuo & $60^{\circ} 05^{\prime}$ & $\mathrm{RaN}$ & 6.4 & 4710 & 35.2 & 10.3 & 285 & 26 \\
\hline 15. Nigula Raba & $57^{\circ} 40^{\prime}$ & $\mathrm{KeR}$ & 5.3 & 8030 & 29.5 & 23.0 & 125 & 65 \\
\hline 16. Big Heath & $44^{\circ} 06^{\prime}$ & "TR" & 4.9 & 7780 & 20.5 & 10.1 & 209 & 33 \\
\hline
\end{tabular}

$\dagger$ LOSS $=\mathrm{p}^{\prime}$ minus $\mathrm{A}^{\prime}$

$\ddagger$ SEQU $=$ fraction of $A^{\prime}$ of $p^{\prime}$ in the model

(Fig. 4). We observed the lowest value, $8.7 \mathrm{~g} \mathrm{C} \mathrm{m}^{-2} \mathrm{a}^{-1}$, in the southwest margin with a tall-sedge fen-type vegetation, and the highest value, $33.7 \mathrm{~g} \mathrm{C} \mathrm{m}^{-2} \mathrm{a}^{-1}$, in the adjoining marginal slope with a Ledum pine bog cover. In addition to mire vegetation types, the differences in the basal and surface topography most obviously are significant when researching a cause for variations of LORCA in different parts of the mire.

The spatial arrangement of the basal peat ${ }^{14} \mathrm{C}$ dates indicates that mire formation in Reksuo started in a topographical depression at the center of the present-day mire ca. 8500 cal BP (Korhola 1992). The subsequent spread of the mire then took place in the form of numerous paludification pulses regulated by the basal topography of the mire. The lateral extension occurred rapidly, until ca. 3500 cal BP, by which time the mire had achieved ca. $92 \%$ of its present area (Korhola 1994). Since that time, there has been a clear decline, almost a halt, in the expansion rate.

Quite the reverse situation seems to exist for vertical growth of the mire. As Figure 5 shows, the mire was still only ca. $1.0-1.5 \mathrm{~m}$ thick $c a .5000 \mathrm{cal} \mathrm{BP}$, with no indication of the present-day domed structure, a feature that clearly shows the minerotrophic character of the mire at that time. Most of the vertical growth of the bog has occurred within the last $c a .3500 \mathrm{yr}$, during which time there was almost no lateral spread in the entire mire. We estimate that ca. 2/3 of the volume (raw units) of the
mire formed within the last ca. $3500 \mathrm{yr}$.

The significant increase in vertical peat accumulation in Reksuo in recent times is also evident in low bulk density and high carbon accumulation values in the upper parts of the studied profiles. In core RB-3 (Fig. 6), for example, a marked change from loose $\left(30-40 \mathrm{~g} \mathrm{dm}^{-3}\right)$ to heavier or denser $\left(>60 \mathrm{~g} \mathrm{~m}^{-3}\right)$ peat may be observed at $\sim 540 \mathrm{~cm}$, corresponding to a ${ }^{14} \mathrm{C}$ age of ca. $5000 \mathrm{cal} \mathrm{BP}$. We also estimated that ca. $60 \%$ of the present peat (bulk) mass deposition and $c a .62 .9 \%$ of the total rate of carbon accumulation date from the last ca. $3500 \mathrm{yr}$ in the same core (Fig. 6). In core RB-2, the corresponding figures were $81.1 \%$ and $62.5 \%$, and in core RB-4, $72.6 \%$ and $63.5 \%$. Thus, we feel jus- 
TABLE 2. Radiocarbon Dates from Reksuo with Calculated Bulk Densities (BD) and LORCA

\begin{tabular}{|c|c|c|c|c|c|c|c|}
\hline $\begin{array}{l}\text { Sample } \\
\text { code }\end{array}$ & Lab no. & $\begin{array}{c}\text { Sample } \\
\text { depth (cm) }\end{array}$ & $\begin{array}{l}\delta^{13} \mathrm{C} \\
(\% 0) \\
\end{array}$ & $\begin{array}{l}{ }^{14} \mathrm{C} \text { age } \\
\text { (yr BP) }\end{array}$ & $\begin{array}{l}\text { Most prob. } \\
\text { date } \\
\text { (cal yr BP) } \\
\end{array}$ & $\begin{array}{c}\text { Average BD } \\
\left(\mathrm{g} \mathrm{dm}^{-3}\right)\end{array}$ & $\begin{array}{c}\text { LORCA } \\
\left(\mathrm{g} \mathrm{C} \mathrm{m}^{-2} \mathrm{a}^{-1}\right)\end{array}$ \\
\hline \multicolumn{8}{|c|}{ Basal peats } \\
\hline RA-1 & Hel-2894 & $160-170$ & -26.9 & $4720 \pm 110$ & 5460 & 56.2 & 8.7 \\
\hline RA-2 & Hel-2895 & $372-379$ & -28.3 & $3610 \pm 110$ & 3890 & 69.1 & 33.7 \\
\hline RA-3 & Hel-2896 & $622-632$ & -26.9 & $6510 \pm 110$ & 7390 & 58.6 & 25.0 \\
\hline RA-4 & Hel-2897 & $654-664$ & -28.0 & $6250 \pm 110$ & 7170 & 61.5 & 28.3 \\
\hline RA-5 & Hel-2898 & $471-480$ & -27.5 & $4050 \pm 100$ & 4520 & 59.8 & 31.8 \\
\hline RA-6 & Hel-2899 & $283-292$ & -28.1 & $3190 \pm 90$ & 3390 & 69.9 & 29.9 \\
\hline RA-7 & Hel-2900 & $113-120$ & -27.5 & $2140 \pm 100$ & 2130 & 87.3 & 24.7 \\
\hline RB-1 & Hel-2901 & $168-177$ & -26.8 & $2740 \pm 110$ & 2810 & 86.4 & 27.4 \\
\hline RB-2 & Hel-2902 & $400-410$ & -26.7 & $4310 \pm 100$ & 4870 & 46.7 & 19.7 \\
\hline RB-3 & Hel-2903 & $673-682$ & -29.1 & $7880 \pm 100$ & 8580 & 50.3 & 19.7 \\
\hline RB-4 & Hel-2904 & $567-578$ & -27.7 & $5080 \pm 100$ & 5800 & 55.8 & 29.4 \\
\hline RB-5 & Hel-2905 & $480-490$ & -27.3 & $4900 \pm 100$ & 5650 & 64.4 & 29.0 \\
\hline RB-6 & Hel-2906 & $375-385$ & -26.7 & $4570 \pm 100$ & 5300 & 52.4 & 20.0 \\
\hline RC-1 & Hel-2907 & $663-672$ & -27.1 & $6450 \pm 120$ & 7370 & 52.6 & 23.9 \\
\hline $\mathrm{RC}-2$ & Hel-2908 & $611-621$ & -26.8 & $6570 \pm 80$ & 7400 & 48.9 & 20.4 \\
\hline RC-3 & Hel-2909 & $440-450$ & -28.2 & $6260 \pm 110$ & 7180 & 71.3 & 22.1 \\
\hline \multicolumn{8}{|c|}{ Vertical cores } \\
\hline \multirow[t]{6}{*}{ RB-1 } & Hel-3472 & $20-30$ & -26.3 & $430 \pm 90$ & 500 & & \\
\hline & Hel-3473 & $50-55$ & -26.3 & $810 \pm 100$ & 710 & & \\
\hline & Hel-3474 & $75-80$ & -24.7 & $1120 \pm 90$ & 1040 & & \\
\hline & Hel-3475 & $105-110$ & -24.5 & $1650 \pm 100$ & 1540 & & \\
\hline & Hel-3476 & $125-130$ & -26.0 & $1970 \pm 100$ & 1890 & & \\
\hline & Hel-3477 & $150-160$ & -27.5 & $3270 \pm 100$ & 3470 & & \\
\hline \multirow[t]{5}{*}{ RB-2 } & Hel-3478 & $50-60$ & -19.8 & $350 \pm 90$ & 430 & & \\
\hline & Hel-3479 & $100-110$ & -23.9 & $580 \pm 90$ & 550 & & \\
\hline & Hel-3480 & $150-155$ & -24.9 & $1190 \pm 90$ & 1070 & & \\
\hline & Hel-3482 & $250-260$ & -25.4 & $2210 \pm 100$ & 2270 & & \\
\hline & Hel-3484 & $350-360$ & -24.4 & $2440 \pm 100$ & 2460 & & \\
\hline \multirow[t]{6}{*}{ RB-3 } & Hel-3486 & $50-55$ & -25.7 & $80 \pm 80$ & 80 & & \\
\hline & Hel-3488 & $150-155$ & -26.0 & $1170 \pm 90$ & 1060 & & \\
\hline & Hel-3490 & $250-255$ & -25.7 & $2060 \pm 100$ & 1990 & & \\
\hline & Hel-3494 & $450-457$ & -25.0 & $3390 \pm 100$ & 3630 & & \\
\hline & Hel-3496 & $550-555$ & -27.6 & $4450 \pm 90$ & 5040 & & \\
\hline & Hel-3498 & $630-640$ & -27.7 & $6250 \pm 100$ & 7170 & & \\
\hline RB-7 & Hel-3499 & $160-166$ & -29.0 & $3100 \pm 90$ & 3280 & & \\
\hline
\end{tabular}

tified in concluding that most of the carbon accumulation in Reksuo has taken place within the last ca. $3500 \mathrm{yr}$.

\section{Discussion}

We studied three types of dates: (1) dates based on pollen analysis; (2) dates based on shore displacement data; and (3) direct ${ }^{14} \mathrm{C}$ dates on peat. Palynological dates depend ultimately on comparison of the pollen spectra examined with one or more ${ }^{14} \mathrm{C}$-dated standard diagrams. The reliability of such extrapolated dates depends on the precision of the ${ }^{14} \mathrm{C}$ time scale, and the regional confor- 
mity of the forest succession. To avoid unnecessary risks, we used only commonly recognized regional boundary horizons, such as the appearances of certain tree pollen in the stratigraphy or the boundaries of the established local pollen-assemblage zones. When working with shore displacement data, we tried to select mires that were known to have originated by direct or primary mire formation. However, the basal layers in some peat sections may postdate local ice retreat or shore displacement by 2 to $3 \mathrm{ka}$ (Tolonen 1967; Korhola 1992, 1995).

Direct ${ }^{14} \mathrm{C}$ dating of peat samples also has its problems. The general uncertainty associated with ${ }^{14} \mathrm{C}$ dating of peat includes contamination by younger root material (Zoltai 1991). Further, many of the mires that we studied overlie a thin layer of strongly compacted and highly humified mor humus, presumably derived from a precursory forest vegetation. When dating basal peats, it is uncertain

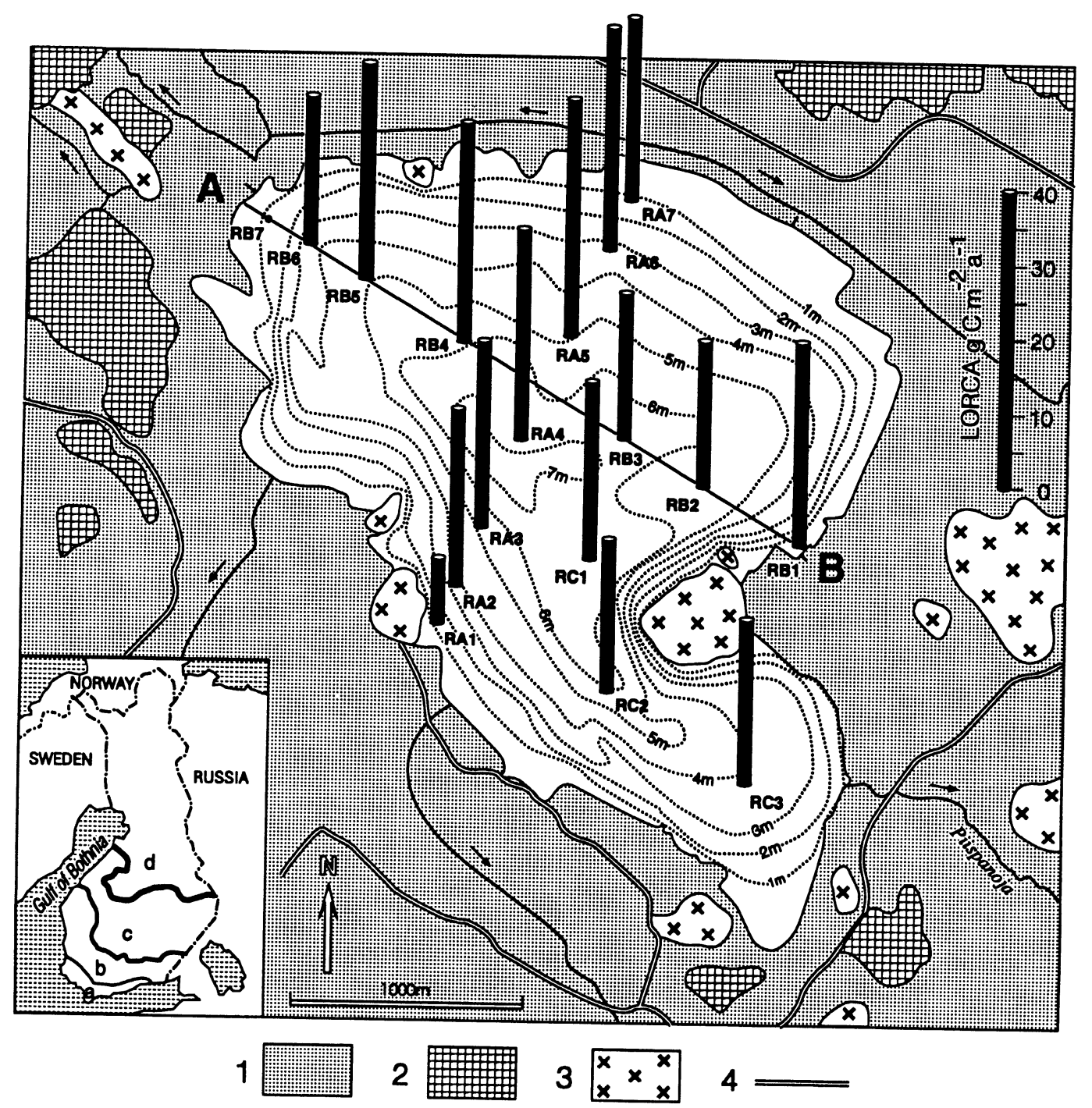

Fig. 4. Reksuo peat bog with depths of peat and average LORCA in 16 peat profiles measured for bulk density. The position of transect $A-B$ is indicated. 1 = field; 2 = peat-covered area; 3 = bedrock outcrop; 4 = local road. 


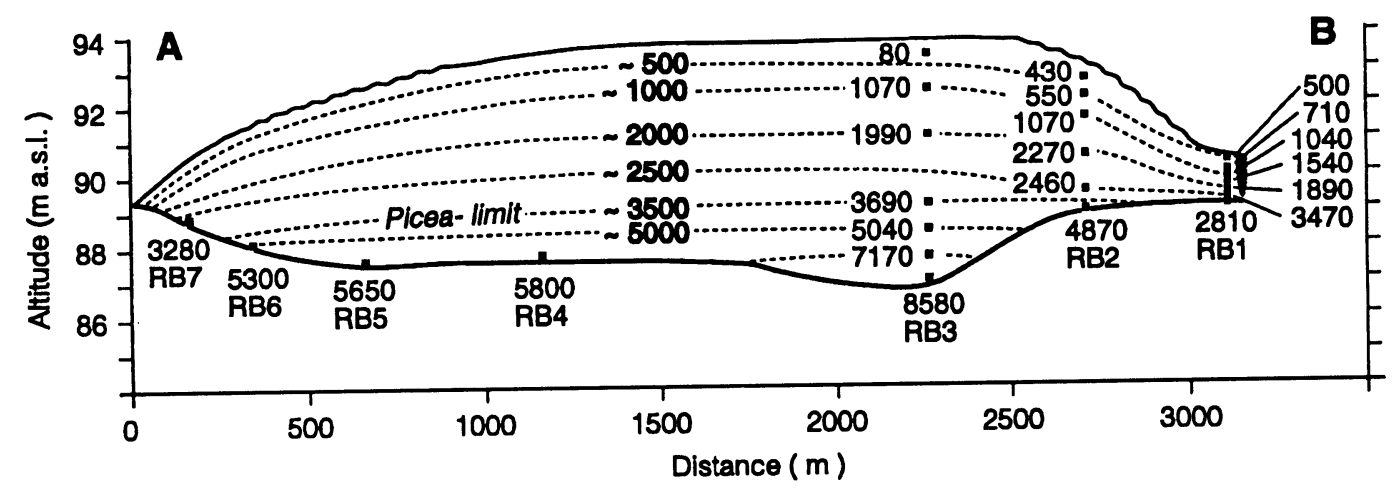

Fig. 5. The reconstruction of bog development in Reksuo along the transect A-B (see Fig. 3) with interpolated isochrones for vertical growth. The boundary for the rise of Picea pollen was determined for sites RB5 and RB6; the Picea limit has been dated in the area to $\mathrm{ca} .3500 \mathrm{cal} \mathrm{BP}$.

whether the mor humus layer or the immediately overlying peat records the true onset of peat formation. We apply the latter here, following Tallis (1991). Also of interest is the possibility that there is some removal of organic carbon from basal peat strata to underlying mineral soil, a hypothetical situation not usually considered when estimating the carbon balance of northern peatlands. The issue needs further clarification.

Long-term average rates of carbon accumulation in peats range from $c a .10 \mathrm{~g} \mathrm{~m}^{-2} \mathrm{a}^{-1}$ to $>50$ $\mathrm{g} \mathrm{m}^{-2} \mathrm{a}^{-1}$ (Billings 1987; Tarnocai 1988; Ovenden 1990), depending on factors that are only partly understood. Against these estimates, our average LORCA figures are generally low, and considerably lower than 29 given by Gorham (1991) for the interior of North America and 30 suggested by Botch et al. (1994) for the mires of the former Soviet Union. The differences may be due to: 1) our material may be skewed because it is concentrated on deep peat layers (mean peat depth $3.03 \pm 1.46$ ); thus, the shallower (and younger?) mires are under-represented; and 2) when using age determinations based on land-uplift chronology, we assumed a maximum age for all the studied mires; consequently, our carbon calculations represent minimum values.

The clear increase in LORCA with decreasing mire age is consistent with previous findings from North America and Alaska (Ovenden 1990; Zoltai 1991; Marion and Oechel 1993)

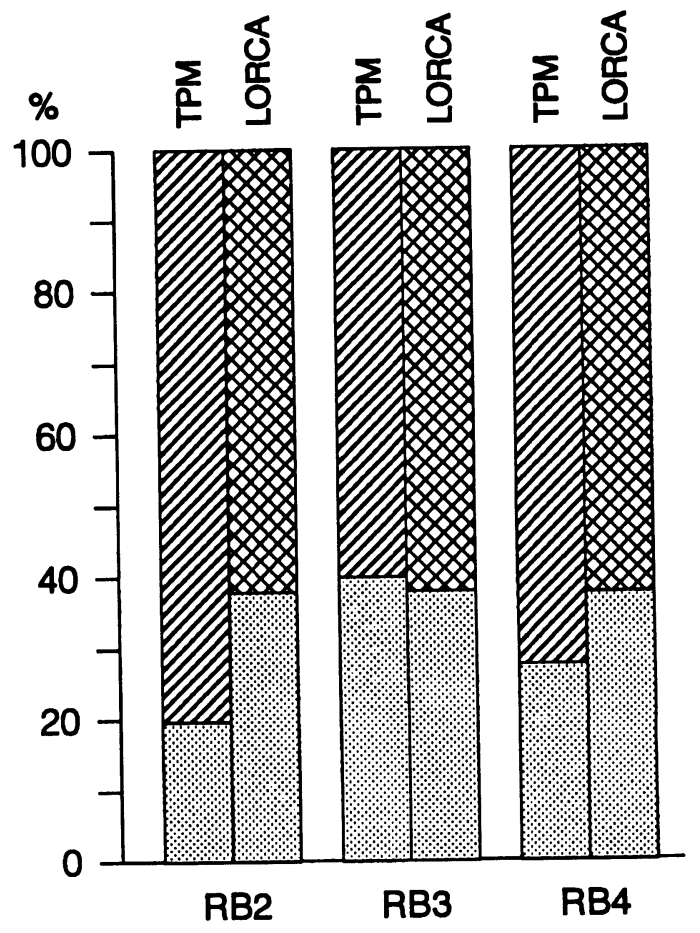

Fig. 6. A histogram showing the percentile proportions of total peat mass (TPM) and total average LORCA with time in three study points in Reksuo. $\mathbb{Z l}=$ proportion of TPM that originated during the last ca. $3500 \mathrm{yr}$ in three study points; $28=$ proportion of LORCA that originated during the last $\mathrm{ca} .3500 \mathrm{yr}$ in three study points. 
and from the former Soviet Union (Botch et al. 1994). Climate change toward wetter conditions $c a$. $4500 \mathrm{cal} \mathrm{BP}$, as documented in lake-level records (Digerfeldt 1988; Harrison and Digerfeldt 1993) and peat initiation data (Korhola 1995) is probably one of the causes that explains this result. Also, older peatlands have obviously experienced more carbon loss by leaching and fires (Hogg et al. 1992). Ecological and morphological changes of natural "aging" of the mire should also be considered. For example, of crucial importance for mire growth is the point in time when Kleinformen, i.e. differentiation of the mire surface into hummock and hollows, start to develop. As postulated by Aario (1932), growth slows from Calluna and lichen cover developing on the hummocks, and by regulation phenomena and the release of marsh gas on the hollows. On the contrary, the marked decline in carbon accumulation for northern mires since $\mathrm{ca} .2000 \mathrm{cal} \mathrm{BP}$ might indicate that aapa fens usually reach their asymptotic steady state (in which there is a balance between the rate of addition and the rate of loss by decay) in an earlier developmental phase than the raised bogs in the south. The great variation in LORCA in different areas, age classes and plant types still necessitates the search for causal factors.

The reliability of the determination for ARCA depends on the number of reliable dates and how realistic the model is. Excluding the unreliable dates (1, 8, 9 and 14; Table 1), we got $0.722 \pm 0.082$ (S.D.) for the ARCA/LORCA ratio at our European sites (Tolonen et al. 1994). In Gorham's (1991) data, the corresponding ratio was 0.79 , with ARCA as $23 \mathrm{~g} \mathrm{C} \mathrm{m}^{-2} \mathrm{a}^{-1}$ and LORCA as $29 \mathrm{~g} \mathrm{C} \mathrm{m}^{-2} \mathrm{a}^{-1}$. In the same data, the carbon sequestering percentage was $c a .56 \%$, very comparable to our average value of $57 \%$. On the basis of these two data sets, we suggest that the current rate of carbon accumulation in Boreal mires is ca. 3.9-7.5\% of annual net primary production, the latter estimated recently (Gorham 1990) as $307 \mathrm{~g} \mathrm{~m}^{-2} \mathrm{a}^{-1}$.

Normally, only a single vertical core is analyzed for carbon accumulation at each site, which means that the horizontal aspect is ignored. Both should be considered, however, because our earlier results (Korhola 1992, 1994) suggest that the processes of vertical and lateral growth are not necessarily interconnected. The findings from Reksuo clearly support this concept, and demonstrate that the present extent of the mire was already reached in the early minerotrophic stage. Since then, the mire has grown mainly vertically, with limited lateral expansion. Most of the carbon accumulation in this ca. 8500 -yr-old bog occurred during the last $c a .3500 \mathrm{yr}$ as a result of strong vertical growth.

\section{ConClusion}

The results presented here strongly contradict the concept of constant input and decay throughout the millennia, and demonstrate that mire ecosystems are complex natural phenomena with a structure, history and dynamics that can be influenced by many internal and external factors. Thus, it is essential to explore mire ecosystems as entire entities. We need to construct additional detailed carbon accumulation records at several points, from the center to the margins of a mire, and to make such measurements on a series of mires of differing depths and vegetation types. This is perhaps the only direction in which to move, if a comprehensive understanding of the long-term peatland carbon accumulation is to be gained.

\section{ACKNOWLEDGments}

This study was supported by the The Finnish Research Programme on Climate Change (SILMU) of The Academy of Finland Grant to K. Tolonen, J. Turunen, H. Jungner and by The Academy of Finland Grant 1017383 to A. Korhola. We thank M. Kilian for comments on the manuscript. 


\section{REFERENCES}

Aario, L. 1932 Pflanzentopographische and paläeogeographische Mooruntersuchungen in W-Satakunta. Fennia 55(1): 1-179.

Billings, W.D. 1987 Carbon balance of Alaskan tundra and taiga ecosystems: Past, present and future. Quaternary Science Reviews 6: 165-177.

Botch, M. S., Kobak. K. I., Vinson, T. S. and Kolchugina, T. P. (ms.) 1994 Carbon pools and accumulation in peatlands of the former Soviet Union. Submitted to Global Biogeochemical Cycles.

Clymo, R.S. 1984 The limits to peat bog growth. Philosophical Transactions of the Royal Society of London B 303: 605-654.

Crill, P., Bartlett, K. and Roulet, N. 1992 Methane flux from Boreal peatlands. Suo (Mires and Peat) 43(4-5): 173-182.

Digerfeldt, G. 1988 Reconstruction and regional correleation of Holocene lake-level fluctuations in Lake Bysjön, South Sweden. Boreas 17: 165-182.

Eurola, S., Hicks, S. and Kaakinen, E. 1984 Key to Finnish mire types. In Moore, P. D., ed., European Mires. London, Academic Press: 11-117.

Foster, D. R. and Wright, H. E., Jr. 1990 Role of ecosystem development and climate change in bog formation in central Sweden. Ecology 71(2): 450-463.

Gorham, E. 1990 Biotic impoverishment in northern peatlands. In Woodwell, G. M., ed., The Earth in Transition: Patterns and Processes of Biotic Impoverishment. Cambridge: Cambridge University Press: 6598.

1991 Northern peatlands: Role in the carbon cycle and probable responses to climatic warming. Ecological Applications 1(2): 182-195.

Gorham, E. and Janssens, J. A. 1992 The paleorecord of geochemistry and hydrology in northern peatlands and its relation to global change. Suo (Mires and Peat) 43(4-5): 117-126.

Harden, J. W., Sundquist, E. T., Stallard, R. B. and Mark, R. K. 1992 Dynamics of soil carbon during deglaciation of the Laurentide ice sheet. Science 258: 19211924.

Harrison, S. P. and Digerfeldt, G. 1993 European lakes as palaeohydrological and palaeoclimatic indicators. Quaternary Science Reviews 12: 233-248.

Hogg, E. H., Lieffers, V. J. and Wein, R. W. 1992 Potential carbon losses from peat profiles: Effects of temperature, drought cycles and fire. Ecological Applications 2: 298-306.

Korhola, A. 1992 Mire induction, ecosystem dynamics and lateral extension on raised bogs in the southern coastal area of Finland. Fennia 170: 25-94.

1994 Radiocarbon evidence for rates of lateral expansion in raised mires in southern Finland. Quater- nary Research 42(3): 299-307.

1995 Holocene climatic variations in southern Finland reconstructed from peat initiation data. The Holocene 5(1): 43-58.

Marion, G. M. and Oechel, W. C. 1993 Mid- to Late-Holocene carbon cycle. In Boer, M. and Koster, E., eds., Greenhouse Impact on Cold-Climate Ecosystems and Landscapes: Selected Papers of the European Conference on Landscape Ecological Impact of Climatic Change. Catena Supplements 22. Cremlignen-Destedt, Catena Verlag: 97-110.

Ovenden, L. 1990 Peat accumulation in northern wetlands. Quaternary Research 33: 377-386.

Rancken, H. 1912 Lapin suomaiden kehityksestä (On the development of the peatlands in Lapland) Suomen Suoviljelysyhdistyksen Vuosikirja 3: 1-87 (in Finnish).

Stuiver, M. and Reimer, P. J. 1993 Extended ${ }^{14} \mathrm{C}$ data base and revised CALIB $3.0{ }^{14} \mathrm{C}$ age calibration program. In Stuiver, M., Long, A. and Kra, R. S., eds., Calibration 1993. Radiocarbon 35(1): 215-230.

Tallis, J. H. 1991 Forest and moorland in the South Pennine uplands in the Mid-Flandrian period. III. The spread of moorland - local, regional and national. Journal of Ecology 79: 401-415.

Tarnocai, C. 1988 Wetlands in Canada: Distribution and characteristics. In Schiff, H. I. and Barrie, L. A., eds., Global Change, Canadian Wetlands Study. Canadian Institute for Research in Atmospheric Chemistry, York University, North York, Canada: 21-25.

Tolonen, K. 1967 Über die Entwicklung der Moore im finnischen Nordkarelien. Annales Botanici Fennici 4: 219-416.

Tolonen, K., Vasander, H., Damman, A. W. H and Clymo, R. S. 1992a Rate of apparent and true carbon accumulation in boreal peatlands. Proceedings of the 9 th $\mathbf{I n}$ ternational Peat Congress, Vol. 1. Uppsala, International Peat Society: 319-333.

1992b Preliminary estimate of long-term carbon accumulation and loss in 25 Boreal peatlands. Suo (Mires and Peat) 43(4-5): 277-280.

Tolonen, K., Turunen, J. Vasander, $H$. and Jungner, $H$. 1994 Rate of carbon accumulation in boreal mires. In Kanninen, M. and Heikinheimo, P., eds., The Finnish Research Programme on Climate Change. Second Progress Report. Publications of the Academy of Finland 1/94: 297-302.

Warner, B. G., Clymo, R. S. and Tolonen, K. 1993 Implications of peat accumulation at Point Escuminac, New Brunswick. Quaternary Research 39: 245-248.

Zoltai, S. C. 1991 Estimating the age of peat samples from their weight: A study from west-central Canada. The Holocene 1(1): 68-73. 